\title{
Język reklamy jako narzędzie perswazji i manipulacji na przykładzie wybranych polskich spotów telewizyjnych
}

\section{Language of advertising as a manner of persuasion and manipulation on the basis of some Polish television commercials}

\author{
Agnieszka Fus \\ Kolo Naukowe Lingwistyki Stosowanej \\ Uniwersytet Rzeszowski \\ ul. Rejtana 16c, 35-959 Rzeszów
}

\begin{abstract}
This article concerns language devices, which are used in television commercials and which are a manner of persuasion and manipulation. The important part of this article is to present the most popular slogans, their influence on us - consumers and the correlation between language of the television commercials and colloquial language. Not only will I focus on neologisms, which introduce the atmosphere of unusualness and convince a receiver about special advantages of the advertised products, but also on the phenomenon of anthropomorphism and personification. This article shows, how authors of television commercials manipulate their consumers, i.a. by introducing created by themselves terms, which imitate scientific terms and apply implicature and presupposition. All described language phenomena are presented on chosen by me examples from Polish television commercials.
\end{abstract}




\section{Wprowadzenie}

Trudno wyobrazić dziś sobie świat bez reklamy. Żyjemy w epoce propagandy slownej, a reklama wciska się we wszystkie obszary otaczającej nas rzeczywistości. Reklama jest już nie tylko podstawa handlu i marketingu w gospodarce wolnorynkowej, ale staje się również elementem kultury.

Od reklamy w zasadzie nie da się uciec. Zapewne każdemu z nas zdarzyło się kupić coś pod jej wplywem. Ważne jest jednak, by być odbiorcá świadomym jej chwytów - w tym środków językowych oraz mechanizmów dzialania. Wszystko po to, by nie być bezwolnym konsumentem, który kupuje wiele rzeczy, nie zważając na ich przydatność.

(3) Definicja reklamy

Podstawą do zrozumienia istoty reklamy, jej języka oraz specyfiki tekstu reklamowego jest uzmyslowienie sobie, czym dokladnie jest reklama oraz co jest jej priorytetem (por. Jhally 1995: 77).

Slowo reklama pochodzi od lacińskiego 'reclamo', które oznacza krzyczeć do kogoś. W przeszlości w ten sposób zachęcano przechodniów do zatrzymania się przed reklamowanym straganem (por. Janich 1999: 16). SJP (1998) podaje, że reklama „to rozpowszechnianie informacji o towarach, ich zaletach, wartościach, miejscach i możliwościach nabycia, chwalenie, zalecanie czegoś przez prasę, radio i telewizję oraz inne środki, plakaty, napisy, ogłoszenia".

Natomiast w SWJP (1999) czytamy, że reklama to „oddzialywanie polegające na perswazji oraz ksztaltowaniu opinii i gustów klienta, stosowane przez producenta i sprzedawcę w celu takiego poinformowania klienta o towarze czy usludze, aby wzbudzić jego zainteresowanie i naklonić do kupna".

(4) Perswazja i manipulacja w komunikatach reklamowych

W zależności od rodzaju reklamy (telewizyjna, radiowa, prasowa) oddzialują na nas kolory, obrazy, muzyka, ale przede wszystkim slowa, dlatego sila perswazji ${ }^{1}$ reklamy w dużej mierze

Perswazja (łac. persuasio) to wplywanie na kogoś w celu przekonania go do czegoś, namawianie lub odradzanie (por. SWO). 
zależy od doboru środków językowych. Istnieje wiele - bardziej i mniej skomplikowanych - definicji perswazji. W przypadku komunikatów reklamowych - definiuję ja jako „drogę do naszego TAK" (Fus 2009), na którą wchodzi reklamodawca, by przekonać nas do nabycia oferowanego produktu, ponieważ glównym celem reklamodawców jest osiągnięcie jak największego popytu na konkretny produkt.

Tekst o charakterze perswazyjnym odnosi się do dwóch sfer: do sfery racji (prezentuje zalety oferowanej rzeczy) oraz sfery emocji - „gra na uczuciach" (por. Wegner 1997: 295). Celem perswazyjnym komunikatu reklamowego jest zachęcenie konsumenta do dzialania, wzbudzenie i utrzymanie w nim przekonania, że wybór jakiego dokonuje, daje mu pelną satysfakcję oraz zasugerowanie mu uzasadnienia dla już dokonanego wyboru.

Obecna w reklamie perswazja wykorzystuje znaczenia słów i ich polączeń, jak również te znaczenia, które niesie ze sobą gramatyka (por. Bralczyk 1995: 27). Reklama wywiera duży wplyw na odbiorców również poprzez manipulację językiem oraz świetnie dopracowanągrę slów. Manipulacja shuży tu osiagnięciu wlasnych korzyści nadawcy, zawiera też pierwiastek oszustwa, jak np. naginanie bądź przeinaczanie pewnych faktów (por. Bralczyk 1995: 27). Wlaśnie ten ,pierwiastek oszustwa" jest najważniejszym elementem różniącym perswazję od manipulacji; ta ostatnia jest w mojej opinii z zalożenia negatywna.

My jako odbiorcy reklam zdajemy sobie sprawę, że ich zasadniczym celem nie jest dostarczanie informacji o danym produkcie, ale zachęcanie do nabycia go. $Z$ drugiej jednak strony chcemy wierzyć, że będzie odwrotnie. Twórcy reklam nadają więc tym komunikatom pozory autentyczności, co ma zamaskować ich perswazję (por. Bralczyk 1995: 25). W zależności od reklamowanego przedmiotu mogą występować prawie same elementy perswazyjne, np. w reklamach zabawek czy słodyczy, których adresatami są glównie dzieci. Zdarza się też, że występuje wiele elementów informacyjnych, np.

Manipulacja (łac. 'manipulatio' - manewr, fortel, podstęp) jest dzialaniem o charakterze perswazyjnym, mającym na celu ksztaltowanie postaw lub zachowań odbiorców w taki sposób, by nie byli w stanie rozpoznać technik i zabiegów stosowanych przez nadawcę (SJP). 
w reklamach samochodów, sprzętu AGD, które skierowane są do osób dorosłych (por. Bralczyk 1995: 26). Jednym z najważniejszych zadań reklamodawców jest zatem określenie grupy docelowej oraz odczytanie jej preferencji. Kolejnym krokiem nadawcy komunikatu reklamowego jest dopasowywanie się do odbiorcy i wzbudzenie jego sympatii (por. Janich 1999: 16).

Poprzez użycie różnych środków językowych nadawca próbuje identyfikować się z odbiorca. Np. w reklamie suplementu diety wspomagajacego koncentrację nadawca odwoluje się do sytuacji bliskiej każdemu studentowi - dużo trudnych egzaminów i mało czasu na naukę. Jak latwo można zauważyć, adresatami reklamy tej są studenci. Nadawcą także jest student. W ten sposób powstaje tzw. wspólny świat nadawcy i odbiorcy. Sprytnym zabiegiem marketingowym jest dodatkowo sama nazwa preparatu - Sesja oraz dość dwuznaczny slogan propagujacy: „Kup sobie sesję”.

\section{Slogan reklamowy}

Slogan to słowo wywodzące się z języków celtyckich, w których sluagh-ghairm oznaczalo okrzyk wojenny. Specjaliści od reklamy postrzegajągo jako przyklad użycia języka w charakterze broni przed konkurencją (por. Braun/Stephan 2000: 11). Slogan wyklucza możliwość odpowiedzi, charakteryzuje się ogólnikowością i odzwierciedla perswazyjną funkcję reklamy. Dobrze skonstruowany slogan dziala jak wirus - przyciaga uwage, zostaje latwo zapamiętany, działa na podświadomość i szybko zyskuje popularność.

Istnieje wiele rodzajów sloganów reklamowych (por. Sowinski 1998: 59). Do najczęściej spotykanych należą:

Slogan bezpośrednio skierowany do klienta: Jesteś tego warta (Loreal), Najlepsze jeszcze przed Tobq (Piast)

Indywidualizowanie odbiorcy jest bardzo ważnym i od dawna stosowanym czynnikiem przekonywajacym. Schlebianie i komplementowanie odbiorcy bardzo korzystnie wplywa na odbiór reklamy i wzmaga atrakcyjność produktu. 
- Slogan prestiżowy: Luxus, na który Cię stać (Toyota Camry),

- Slogan komunikujący nowość i jakość: Nowa jakość życia (Whirpool)

- Slogan oddzialujacy na zmysly i emocje: Kawa zwana pożadaniem $^{3}$ (Carte Noir); Daj się skusić (Milka); Daj się ponieść Fantazji (Danone); Feel attractive!, Feel sensual! (Silan)

- Slogan wzbudzający ciekawość: Wiedzieć więcej niż inni (rtr); ERA. Możesz więcej.

- Slogan podkreślajacy korzystną cenę: Codziennie niskie ceny (Biedronka)

- Slogan kontekstowy: Ryba wplywa na wszystko (promocja rozwoju rybolówstwa)

- Slogan rozkazujący: Podaj to, co najlepsze (Tchibo); Badź sobq, wybierz Pepsi!

Reklamowe $T Y$ zmniejsza dystans między nadawcą i odbiorca, sprawia że zostaje zaznaczona nasza obecność i budzi się nasze ego. Koncentrację na odbiorcy wzmacnia także zaimek dzierżawczy twój, np. Twój dzień. Twoja woda (Arctic). Dzięki temu reklama jest bardziej wiarygodna, gdyż odbiorca odnosi wrażenie, że jest ona kierowana tylko do niego.

\section{Tworzenie wyjątkowej atmosfery}

Istotnym czynnikiem dzialającym na wyobraźnię odbiorcy jest budowanie atmosfery niecodzienności i niezwykłości. Korzystaja z tego specjaliści od reklamy, używając neologizmów: czasowstrzymywacz, Szczęście sprzyja lodożercom, Play fresh-najlepsza oferta na kartę. Freszcie! (Plus GSM).

Reklamodawcy sięgają również po frazeologizmy: Tetley - smak prawdziwej herbaty na okrqglo, Plus GSM - zmieniamy świat na plus. Niekiedy slogany pośrednio nawiąują do związków

Nawiązanie do tytułu słynnej sztuki Tennessee Williama Tramwaj zwany pożadaniem. 
frazeologicznych, np.: Activia: reguluje i smakuje, Nimm 2: lakocie $i$ witaminy (czyli polączenie przyjemnego z pożytecznym).

Twórcy reklam poslugują się dodatkowo antropomorfizacja, np. Dhuższe życie każdej pralki to Calgon; Nowy Opel Agila-oszczędny i przyjazny środowisku; Whirpool proponuje chlodziarko-zamrażarkę, która jest przyjazna dla otoczenia ... a Jutrzenka zachwala Cukierki Akuku - te nadziane. Na ostatnim przykladzie widać, że reklama czerpie $z$ języka potocznego.

Obok antropomorfizacji twórcy reklam sięgaja po personifikację, np. karma Whiskas jest tak dobra, że gdyby kot tylko mógł, to sam by ją kupowal (Twój kot kupowalby Whiskas). Zatem kot zyskuje w tej reklamie cechy ludzkie. Podobnie jest ze świstakiem, który w reklamie czekolad "siedzi i zawija je w te sreberka”.

Ostatnie hasło weszlo $\mathrm{z}$ reszta na stale do powiedzonek języka potocznego, podobnie jak: A lyzka na to: Niemożliwe! (Rama) czy A mnie to lotto; Mala rzecz a cieszy (Princessa), czy wreszcie pierwszy powojenny slogan reklamowy: Coca-cola to jest to. To jest to mówimy do dziś o wszystkim, kiedy chcemy podkreślić jakość lub wyjątkowość czegoś.

\subsection{Reklamowe tabu}

Poprzez odpowiednie sformułowanie sloganu nadawcy komunikatów reklamowych maskują swoją intencję zysku, gdyż jest ona tutaj jedynym tematem objętym językowym tabu. Osiaggają to, stosując maksymę taktu oraz maksymę wspaniałomyślności (Nęcki 2000: 17). Maksyma taktu oznacza minimum wysilku dla klienta i maksimum korzyści dla niego, zaś maksyma wspaniałomyślności to minimum korzyści dla producenta bądź uslugodawcy i maksimum wysilku dla niego. Widać to w następujących komunikatach: U nas najdroższy jest klient (Euronet); Link 4. Zadzwoń. Resztę zrobimy za Ciebie. Hasło Unas najdroższy jest klient można określić jako „dwa w jednym”. Klient jest najważniejszy, a produkty oferowane przez ten sklep nie sa zbyt drogie. Obydwie te cechy sa pożądane spolecznie, a marka Euronet sprytnie przypisuje je sobie. 
Przy tej okazji warto skupić się na cenie popularyzowanych produktów. Specjaliści od reklamy raczej unikaja slowa "tani”, które mogloby sugerować, że klient nie zwraca uwagi na jakość produktu, ale kieruje się wylącznie ceną. Stosują więc eufemizmy cenowe, np. Dosia oferowala kiedyś Jakość za rozsqadnq cenę, dziś Vanish wypierze wszystko prócz kieszeni a Mc Donald's kusi strefa dobrych cen.

Jak już wspomnialam, twórcy reklam przemilczają chęć odniesienia korzyści, jednocześnie podkreślając swoją dobroczynną dzialalność na rzecz środowiska lub chorych dzieci. Producent wody Żywiec podkreśla, że dzięki niemu i jego klientom posadzono już milion drzew, firma Procter\&Gamble wspiera Fundację TVN „Nie jesteś sam” a Cisowianka buduje studnie w Sudanie. Odbiorca odnosi wrażenie, że przedmiotem komunikatu jest działalność firmy, a niekoniecznie reklamowany produkt. Poprzez kreowanie dobrego wizerunku firmy chwalenie się reklamodawcy zostaje zneutralizowane. Pozytywna autoprezentacja to skuteczny zabieg perswazyjny, którego celem jest wytworzenie podziwu i wzbudzenie sympatii odbiorcy oraz sprowokowanie go do dzialania, czyli nabycia reklamowanego produktu.

\section{2. "Naukowe" sztuczki reklamodawców i powolywanie się na autorytety}

Silę naklaniającą komunikatu reklamowego bardzo wzmacnia nadanie mu charakteru wypowiedzi naukowej poprzez powołanie się na poważne instytucje, jak np. Instytut Żywności i Żywienia lub odpowiednie wykreowanie postaci wyrażającej swoją opinię. Wypowiedź osoby w białym kitlu, podkreślającej swój zawód i występujacej w roli autorytetu ma na celu przekonać potencjalnego konsumenta o sluszności wyboru danego leku, szamponu, kremu czy pasty do zębów. W podobny sposób wiarygodność podbudowuje zwrot: Chlodnym okiem eksperta. Nowe lodówki Amica sq wprost wymarzone do Twojej kuchni. Wydawałoby się, że obiektywnej opinii specjalisty można bez wahania zaufać. Po krótkim zastanowieniu nasuwa się jednak pytanie: Który to ekspert jest w stanie określić, jaka lodówka pasuje do mojej kuchni nawet bez zobaczenia 
pomieszczenia, czy zapytania o moje oczekiwania odnośnie sprzętu? Widać tu wyraźnie manipulacyjny charakter wypowiedzi.

Sposobem nadania reklamie charakteru naukowego jest ponadto wprowadzanie do niej zwrotów naukowych bądź terminów niejasnych dla odbiorcy. Przykladem tego jest reklama Actimela, bogatego w bakterie L.casei defensis. Bakterie L.casei to znane od dawna probiotyki, zaś czlon defensis jest wylącznie chwytem reklamowym. We Włoszech zamiast defensis wymyślono imunitass. Jest to zatem przyklad czystej manipulacji.

\subsection{Zjawisko implikatury i presupozycji}

Jaskrawym przejawem manipulacji jest szarżowanie liczebnością w reklamie baterii Duracell, które „dzialają do siedmiu razy dhużej”. To znaczy, że moga mieć one taką samą wytrzymalość jak zwykle baterie albo dzialać dwa, trzy i tak do sześciu razy dlużej, ale nie siedem. Odbiorca tego komunikatu nie poddaje go jednak tak dokladnej analizie i przyjmuje, że baterie te są siedem razy wytrzymalsze od innych, a więc najlepsze.

Podobny charakter do omówionego sloganu baterii Duracell ma haslo: Żaden proszek nie usunie tych plam lepiej (Vizir). Mamy tu do czynienia ze zjawiskiem implikatury, czyli ,pragmatycznym wnioskowaniem, opartym na konwencjonalnym znaczeniu wypowiedzenia" (Bralczyk, 1995: 205) Komunikat ten wcale nie mówi o tym, że dany proszek jest najlepszy a tylko sugeruje to. Równocześnie nadawca nie zaprzecza, że inne proszki są równie dobre. Odbiorca natomiast myśli, że wlaśnie ten proszek jest najskuteczniejszy. Konsument nie zajmuje się logicznym analizowaniem tego przekazu reklamowego, z którego wynika jedynie, że inny proszek nie wypierze lepiej, ale może zrobić to tak samo dobrze.

Specjaliści od reklamy często wykorzystuja jeszcze jedną drogę manipulacji - technikę presupozycji. Wedlug Bralczyka (1995: 208) presupozycja jest sadem umożliwiajacym wypowiedzenie zdania zawierajaccego inny sąd, np.: Dlaczego Polacy najczęściej wybieraja Apap?. Osoba reklamujaca lek wyraża tym komunikatem swoje osobiste przekonanie. Jest to jednak próba narzucenia go odbiorcy, 
ponieważ przedstawia ona swoje stanowisko w sposób autorytatywny, nie ulegający watpliwości. Reklamodawca przyjmuje tu, że konsumenci nie zaprzeczą temu sądowi, gdyż są zbyt leniwi, by wykazać się aktywną postawą i wysunąć kontrargumenty. Presupozycja zostaje zatem uznana za autentyczną.

Przy okazji reklamy leku Apap warto zwrócić uwage na rolę pytań w reklamie. Już Sokrates uważal je za bardzo dobre narzędzie komunikacyjne w sztuce perswazji. Szczególne ich możliwości wynikaja $z$ faktu, że odbiorca komunikatu odpowiada na nie niby wedlug wlasnego uznania. Pytania jednak są tak formulowane, że z reguly tylko jednak odpowiedź wydaje się rozsądna.

\section{Podsumowanie}

Twórcy przekazów reklamowych świetnie poslugują się technikami oddzialywania na nasze spostrzeżenia i emocje. Reklama to swoista gra nadawcy z konsumentem. Ten pierwszy mówi językiem odbiorcy oraz utożsamia się z jego potrzebami. Konsumentowi zaś świat reklam jawi się jako raj. By uwierzyć w siebie, wystarczy lyk Coca-coli, poczucie atrakcyjności zapewnia Silan a Red bull dodaje skrzydel...

Podsumowując zadajmy więc sobie pytanie: Czy reklama mówi prawdę? Można odpowiedzieć: Prawie... A prawie robi duża różnice... (Żywiec).

\section{Bibliografia}

Bralczyk J. 1995. Język na sprzedaż. Gdańskie Wydawnictwo Psychologiczne.

Braun Ch., Stephan I. 2000. Gender Studien. Eine Einführung. Frankfurt am Main.

Fus A. 2009. Die Darstellung der Frau und Persuasion in der deutschen Werbung der Gegenwart. Nieopublikowana praca magisterska napisana pod kierunkiem prof. Z. Wawrzyniaka. 
Janich, N. 1999. Werbesprache - ein Arbeitsbuch. Tübingen: Narr Verlag.

Jhally S. 1995. Image-based culture. Advertising and popular culture.

W: Dines, G., McMahon J. (red.): Gender, race and class in media. Thousand Oaks.

Nęcki Z. 2000. Negocjacje w biznesie. Kraków: Antykwa.

Wegner, K. 1997. Werbung und Wertorientierung. Ethica. Zeitschrift für Verantwortung in Wissenschaft. Innsbruck: Resch Verlag.

\section{Slowniki}

SJP = Szymczak, M. (red.) 1998. Słownik języka polskiego. Warszawa: PWN.

SWJP = Dunaj, B. (red.) 1999. Slownik wspólczesnego języka polskiego, Warszawa: Wilga.

SWO = Slownik Wyrazów Obcych pod red. W. Glucha (2003). Wroclaw: Europa. 